OPEN ACCESS

Edited by:

Ana Jiménez-Zarco, Open University of Catalonia, Spain

Reviewed by:

Montserrat Díaz-Méndez, University of Extremadura, Spain Juan Miguel Rey-Pino, Universidad de Granada, Spain

*Correspondence: Pedro Cuesta-Valiño pedro.cuesta@uah.es

Specialty section: This article was submitted to Organizational Psychology, a section of the journal Frontiers in Psychology

Received: 26 September 2021 Accepted: 27 October 2021 Published: 25 November 2021

Citation: Loranca-Valle C, Cuesta-Valiño P. Núnez-Barriopedro $E$ and Gutiérrez-Rodríguez P (2021) Management of Loyalty and Its Main Antecedents in Sport Organizations:

A Systematic Analysis Review.

Front. Psychol. 12:783781. doi: 10.3389/fpsyg.2021.783781

\section{Management of Loyalty and Its Main Antecedents in Sport Organizations: A Systematic Analysis Review}

\author{
Cristina Loranca-Valle ${ }^{1}$, Pedro Cuesta-Valiño ${ }^{1 *}$, Estela Núnez-Barriopedro ${ }^{1}$ and \\ Pablo Gutiérrez-Rodríguez ${ }^{2}$
}

${ }^{1}$ Department of Economy and Business Management, Universidad de Alcalá, Alcalá de Henares, Spain, ${ }^{2}$ Department of Business and Economy Management, Universidad de León, León, Spain

Sports management is booming, thanks to society's growing interest in sports in general. This work provides an exhaustive review of the scientific literature of one of the variables most coveted by managers: loyalty. Antecedents positively related to loyalty are also conceptualized in this paper. The scientific literature search was limited to the last 15 years to achieve a better fit with today's context. The Web of Science database was the main search method used, along with other, secondary resources, for a total of 328 scientific articles obtained as a base for this review. The results of this study bring together the most representative data in a systematic review of the loyalty variable in the field of sports management: the antecedents of loyalty, the terms with the greatest presence in the theory, the most representative authors and sources of this topic, and so on. One of the most significant results obtained from the review of these 300 bibliographical references is that the factors to be borne in mind for marketing strategies in sports organizations are satisfaction, commitment, trust, and service quality. The literature reflects that these variables, present in studies on loyalty in general, can also be found in the literature on sports management - in particular, satisfaction and service quality. However, few papers include all these antecedents at once, making this an interesting field for future research.

Keywords: loyalty, sport management, satisfaction, service quality, commitment, trust, systematic review

\section{INTRODUCTION}

Loyalty is one of the principal objectives of marketing and is sometimes even equated to the concept of marketing itself (Sheth, 1996). Loyalty is a variable that has been extensively researched in the literature of psychology, marketing, and management, in which many authors have studied the variables that explain loyalty (Dwyer et al., 1987; Dick and Basu, 1994; Sheth, 1996; Núñez-Barriopedro et al., 2021). There are, however, three variables that are repeated in many proposals and models: satisfaction, trust, and commitment (Garbarino and Johnson, 1999; Hennig-Thurau et al., 2001; Bansal et al., 2004; Rauyruen and Miller, 2007). Service quality is an another variable that most commonly appears in the literature on consumer loyalty, and it is included by authors such as (Cronin and Taylor, 1992; Hur et al., 2011; Kim and Trail, 2011; Mandhachitara and Poolthong, 2011; Pérez-Cabañero et al., 2017). Most authors who study loyalty from a marketing viewpoint do so, firstly, from the perspective of behavioral 
loyalty, i.e., repeating the exchange relationship (Chaudhuri and Holbrook, 2001; Szymanski and Henard, 2001; Chiou and Drogue, 2006), and secondly, from the perspective of attitudinal loyalty (Kunkel et al., 2013, 2019).

The sports industry generates billions of dollars; a better understanding of the relationship between the product and its consumers is thus a key factor for the marketing managers of sport organizations. Maintaining relationships over time, independently of whatever factors may arise, is also of key importance. Loyalty therefore becomes a crucial element in maintaining relationships over time and thus an element on which marketing managers must focus (Tsiotsou, 2013).

Sport organizations include all those bodies that pursue sports-related activities. They may therefore be companies that offer goods (sports clothes, sports apparatus and materials, etc.), services (personal training, broadcasting games on television, etc.), ideas (consequences of belonging to a club or taking part in a sport: slimming, giving members an identity), or a combination of all of these (Smith and Stewart, 2013). The way loyalty is explained may vary as a function of the type of sports product in question and also of the different types of consumer - such as those attending events, those watching, listening to, or reading the media, those purchasing products with licenses, etc. (Kim et al., 2011).

Sports products have unique aspects that affect the basic conditions for selling them: they are products that are inherently uncertain; they are inconsistent and open to subjective interpretations; they take place under highly competitive conditions; and marketing managers for these products do not have full control over the marketing mix (Mullin et al., 2007). It is also true, however, that it has been shown empirically that members of sport organizations tend to behave in their sport and its money-making activities in the same way as in other areas of consumption (Bodet, 2012).

Consumer loyalty is an asset highly valued by all types of organizations and directing available resources toward improving loyalty is much easier if this concept has been analyzed. This work aims to examine the existing literature on loyalty to a sports organization and verify whether the variables that explain loyalty in organizations in general are also present in sports theory. On this basis, the following questions are raised:

Q1: Does loyalty to sports organizations behave in the same way as consumer loyalty to any other organizations?

Q2: Is the quality of sports services a key variable for consumer loyalty?

Q3: Is satisfaction the most representative variable of sports consumer loyalty?

Q4: Can commitment and trust variables explain loyalty in sports?

The following sections aim to offer an exhaustive review of loyalty from the point of view of sports management considering the main antecedents that lead to loyalty in sports organizations. In a first step, the different loyalty concepts and their main antecedents (satisfaction, service quality, commitment, and trust) are analyzed. Then the various sources used are detailed, as well as the main search criteria. The results presented compile the most notable data on the bibliography related to sports loyalty, through a systematic analysis of the literature, while the paper ends with the main conclusions derived from this search.

\section{CONCEPT OF LOYALTY AND ITS MAIN ANTECEDENTS}

Loyalty has been conceptualized by various authors in the fields of both psychology and marketing. Many authors have made in-depth studies of this concept from the marketing perspective, and all agree that loyalty comprises all those behaviors involving same-brand purchasing repeatedly, both now and in the future (Dick and Basu, 1994; Oliver, 1999; Chaudhuri and Holbrook, 2001; Hennig-Thurau et al., 2002; Cuesta-Valiño et al., 2021a), despite situational influences and marketing efforts that have the potential to cause switching behavior (Oliver, 1999).

Loyalty is made up of two concepts, which combine to give the variable the greatest explanatory power. These two concepts are: behavioral aspects or purchase intentions and attitudinal loyalty (Rauyruen and Miller, 2007; Cossío-Silva et al., 2016). Behavioral loyalty has been identified as customers' willingness to repurchase the product or the services and to maintain a relationship with the supplier or service provider. Attitudinal loyalty, however, is the consumer's level of commitment toward a product/brand and their promotional attitude toward the supplier or service provider (Dick and Basu, 1994; Chaudhuri and Holbrook, 2001).

By focusing on loyalty in the field studied in this paper, i.e., sport, it becomes clear that it is more difficult to conceptualize loyalty when the subject is services than when discussing products. This is partly because, in the case of services, it is impossible to separate the consumer from the person providing the service, and this participation by the client in the interpersonal component of services - their production and delivery - adds emotional dimensions to loyalty (Lewis and Soureli, 2006). The individual's underlying willingness to repurchase, together with evaluation of the alternatives, is inseparable from the notion of loyalty (Jacoby and Kyner, 1973).

In recent decades, the literature on loyalty has multiplied and we have found many studies that aim to explain it (see Table 1). These ideas are summarized in the sections below, which explain the principal antecedents of this variable.

\section{Service Quality}

This variable is defined as the discrepancy between a consumer's prior expectations for a given service and his or her perception regarding the purchase or services (Parasuraman et al., 1988; Boulding et al., 1993; Hennig-Thurau et al., 2002). This implies that, for the same perception, the higher the consumer's expectations the lower the perceived quality will be (Parasuraman et al., 1988).

Parasuraman et al. (1985) created a scale to measure quality based on 10 dimensions, which were subsequently summarized 
TABLE 1 | Loyalty definitions.

\begin{tabular}{|c|c|}
\hline References & Definition \\
\hline $\begin{array}{l}\text { Chaudhuri and Holbrook (2001) } \\
\text { Rauyruen and Miller (2007) }\end{array}$ & $\begin{array}{l}\text { Behavioral loyalty is "the willingness of } \\
\text { average business customers to repurchase } \\
\text { the service and the product of the service } \\
\text { provider and to maintain a relationship with } \\
\text { the service provider/supplier." Attitudinal } \\
\text { loyalty is "the level of customer's } \\
\text { psychological attachments and attitudinal } \\
\text { advocacy towards the service provider/ } \\
\text { supplier." }\end{array}$ \\
\hline Oliver (1999) & $\begin{array}{l}\text { "To re-buy or re-patronize a preferred } \\
\text { product/service consistently in the future, } \\
\text { thereby causing repetitive same-brand or } \\
\text { same brand-set purchasing, despite } \\
\text { situational influences and marketing efforts } \\
\text { having the potential to cause switching } \\
\text { behavior" }\end{array}$ \\
\hline Pressgrove and Mckeever (2016) & $\begin{array}{l}\text { "Loyalty is a complex multidimensional } \\
\text { variable with little consensus concerning the } \\
\text { specific dimensions and how they interact } \\
\text { to determine a behavioral outcome" }\end{array}$ \\
\hline
\end{tabular}

into five: (1) tangibles, (2) reliability, (3) responsiveness, (4) assurance, and (5) empathy (Parasuraman et al., 1988). This scale has been the basis of numerous studies on quality in different settings (Gilbert and Wong, 2003; Lee-Ross, 2008; Butt and de Run, 2010; Samen et al., 2013; Farooq et al., 2019), although it has also been criticized by many authors (Cronin and Taylor, 1992; Buttle, 1996; Robledo, 2001). Several authors have created models to explain service quality in specific sectors (Chang and Yeh, 2002; Chen and Chen, 2010; Meesala and Paul, 2018; Hult et al., 2019; Cuesta-Valiño et al., 2020; see Table 2).

\section{Satisfaction}

General satisfaction is a general assessment based on all the purchases and the consumers' experience of using a product or service (Fornell, 1992; Anderson et al., 1994). Another definition of satisfaction is customer's emotional or sentimental reaction to the perceived differences between expectations and actual implementation (Oliver, 1980; Andreassen, 2000). This definition may cause confusion between satisfaction and perceived quality, but these variables are different. The principal difference is that satisfaction is a type of attitude, a perception over the long term, while perceived quality measures a specific transaction (Parasuraman et al., 1988). Zablah et al. (2016) define satisfaction as "subjective evaluation made as a post-choice cognitive judgment," a meaning that follows the same emotional line of Trail et al. (2000) and Maxham and Netemeyer (2002); see Table 3).

\section{Commitment}

Commitment is understood to be the implicit or explicit promise of a long-term relationship between the parties (Geyskens et al., 1996; Ruyter et al., 1998; Dwyer et al., 2015). Simplifying the equation, one can consider commitment to be the motivation
TABLE 2 | Perceived Quality definitions.

\begin{tabular}{|c|c|}
\hline References & Definition \\
\hline Boulding et al. (1993) & $\begin{array}{l}\text { "The consumer's perception of overall service } \\
\text { quality results from a comparison between } \\
\text { expectations and perceptions of the different } \\
\text { components of service. With perceptions of } \\
\text { services held fixed, the higher the } \\
\text { expectations, the lower the perceived quality" }\end{array}$ \\
\hline $\begin{array}{l}\text { Parasuraman et al. (1988) } \\
\text { Su et al. (2016) }\end{array}$ & $\begin{array}{l}\text { "It is a form of attitude, related but not } \\
\text { equivalent to satisfaction, and results from a } \\
\text { comparison of expectations with perceptions } \\
\text { of performance" }\end{array}$ \\
\hline Zeithaml (1987) & $\begin{array}{l}\text { "Perceived Quality is the consumer's } \\
\text { judgment about an entity's overall excellence } \\
\text { or superiority" }\end{array}$ \\
\hline
\end{tabular}

TABLE 3 | Definitions of satisfaction.

\begin{tabular}{ll}
\hline References & Definition \\
\hline Andreassen (2000) & "Satisfaction is consequently related to \\
providing what is being sought to the & point where fulfillment is reached" \\
& "Summary psychological state resulting \\
& when the emotion surrounding \\
Oliver (1981) & disconfirmed expectations is coupled with \\
& the consumer's prior feelings about the \\
& consumption experience" \\
& "Satisfaction is defined as the \\
& contentment of the customer with respect \\
to his or her prior g experience"
\end{tabular}

that pushes a party to trust a given company (Moorman et al., 1993) or the psychological attachment to the organization (Gruen et al., 2000). Commitment implies the conviction by both parties that maintaining the relationship will be more beneficial than ending it (Geyskens et al., 1996). All definitions of commitment agree that there is a psychological component (bond, link, promise, or dedication) and a motivational component (maintaining the relationship; repeated purchasing; remaining in the organization; Jones et al., 2010). Commitment and sport are closely related: indeed, there are multiple works that study the relationship of commitment between the athlete and the sports organization (Mahony et al., 2000; Ross et al., 2006; Rather, 2018; Cuesta-Valiño et al., 2021b). The different meaning of commitment are compiled in Table 4 .

\section{Trust}

Many authors agree that trust is one of the basic ingredients for success in relationships (Dwyer et al., 1987; Moorman et al., 1993; Berry, 1995). Trust in an organization is based on the consumer's certainty of the quality and integrity of the service offered (Moorman et al., 1993; Morgan and Hunt, 1994; Garbarino and Johnson, 1999; Hennig-Thurau et al., 2001). Trust is the belief by one of the parties that the actions the other party takes will necessarily satisfy his/her needs (Anderson and Weitz, 1989). In relationships between the consumer and 
TABLE 4 | Commitment definitions.

\begin{tabular}{ll}
\hline References & Definition \\
\hline Gruen et al. (2000) & "The degree of the membership's \\
& psychological attachment to the \\
& association" \\
"An enduring desire to maintain a valued & relationship" \\
"An exchange partner believing that an \\
ongoing relationship with another is so \\
important as to warrant maximum \\
efforts at maintaining it"
\end{tabular}

TABLE 5 | Trust definitions.

\begin{tabular}{ll}
\hline References & Definition \\
\hline & "The willingness of the average \\
& consumer (user/donor) to rely on the \\
ability of the brand (company/ & organization) to perform its stated \\
function" & \\
"A key condition in the long-term & development of relationships. High \\
levels of trust are said to reduce \\
uncertainty and diminish perceptions of \\
risk in a relationship" \\
"Trust as having two components: \\
performance or credibility trust and \\
benevolence trust"
\end{tabular}

companies, the psychological benefits of security and trust are more important than special treatment or the social benefits arising from that relationship (Gwinner et al., 1998). Trust is an involvement in a process, which has been well thought-out and carefully considered, while brand attachment or affect is spontaneous, more immediate, and less reasoned (Chaudhuri and Holbrook, 2001). Trust, like commitment may have both affective and cognitive dimensions (Johnson and Grayson, 2005). Trust is a positive attribute that gives the members of an organization the necessary commitment to carry out the objectives set (Józefowicz, 2013; see Table 5).

\section{MATERIALS AND METHODS}

Following other examples (Montero and López-Sánchez, 2021; Södergren, 2021), a systematic review of the scientific literature was carried out to identify, classify, and synthesize the existing publications on the loyalty variable in a sports context. The procedure had three steps: identify the literature, extract the data, and present results. In the search stage, the possible articles most suitable for this study were identified using different data sources, such as Google Scholar, Scopus Sage Journals and - above all -Web of Science (WoS). WoS was used as the main source because it contains the publications with the highest impact index, as well as being one of the most extensive databases. Its advanced search formula allows large specifications and helps to classify the studies analyzed.
Loyalty has been a highly studied concept in different areas, that is why the search criteria used have been very specific. Using key words like "loyalty and sport," "loyalty and sport management," "loyalty and satisfaction in sport management," "loyalty and service quality in sport management," "loyalty and commitment in sport management," and "loyalty and trust in sport management." Satisfaction, service quality, commitment, and trust were included in the search criterion because they are the main variables that affect to loyalty in a general context. Figure 1 represents the idea of loyalty and its antecedents transferred to a sport management context.

The search time range covered the last 15 years, from 2006 to 2021. During that period, sport has experienced significant growth - as have all related sectors - and competition between organizations is getting increasingly strong, leading in turn to an increased need to retain the consumer (Wemmer and Koenigstorfer, 2016; Cuesta-Valiño et al., 2021c).

Some 1,154 articles were compiled in the identification phase. These were subsequently reduced to 599 once duplicate articles were eliminated. Several refining phases followed, with the analysis of the abstracts and the keywords included in each article.

In a first step, all those articles not specific to the sports sector were excluded, leaving the database with 438 articles. In a second exclusion phase, all those articles that did not measure the loyalty variable were rejected: 328 articles remained. Figure 2 specifies the flow chart followed in the selection process.

The selection, classification, and exclusion phases were carried out using an Excel file. In the following section, the data extracted - mainly from the WoS - are presented.

\section{RESULT OF BIBLIOMETRIC ANALYSIS}

The results of this review indicate that there are various authors who have vast expertise in sports loyalty. Table 6 shows the authors with the highest number of published articles and the most cited authors among the articles analyzed.

There are numerous magazines that focus on sports and sports management. Moreover, articles on sports loyalty are also published in other journals, such as those with a more general focus or in other specific fields such as tourism or the internet. The magazines that publish the most articles on the subject studied are mainly magazines specific to sports management. Table 7 shows the five journals that publish the most articles on this topic. However, the most cited magazines regarding loyalty in sport have other approaches.

Figure 3 shows the countries that publish contents on loyalty in sport. It is a color map and the stronger color used for a certain country, the more papers published in that country. As can be seen, the United States is the country that has produced the most papers (90 articles), followed by Spain (52), Australia (45), United Kingdom (29) and South Korea (19).

In the literature there are different terms related to loyalty that appear in some of the most accepted definitions of loyalty in the theory, although such definitions differ. An example is the term "purchase intentions" defined in loyalty as the intention to buy from the same organization continuously over time 


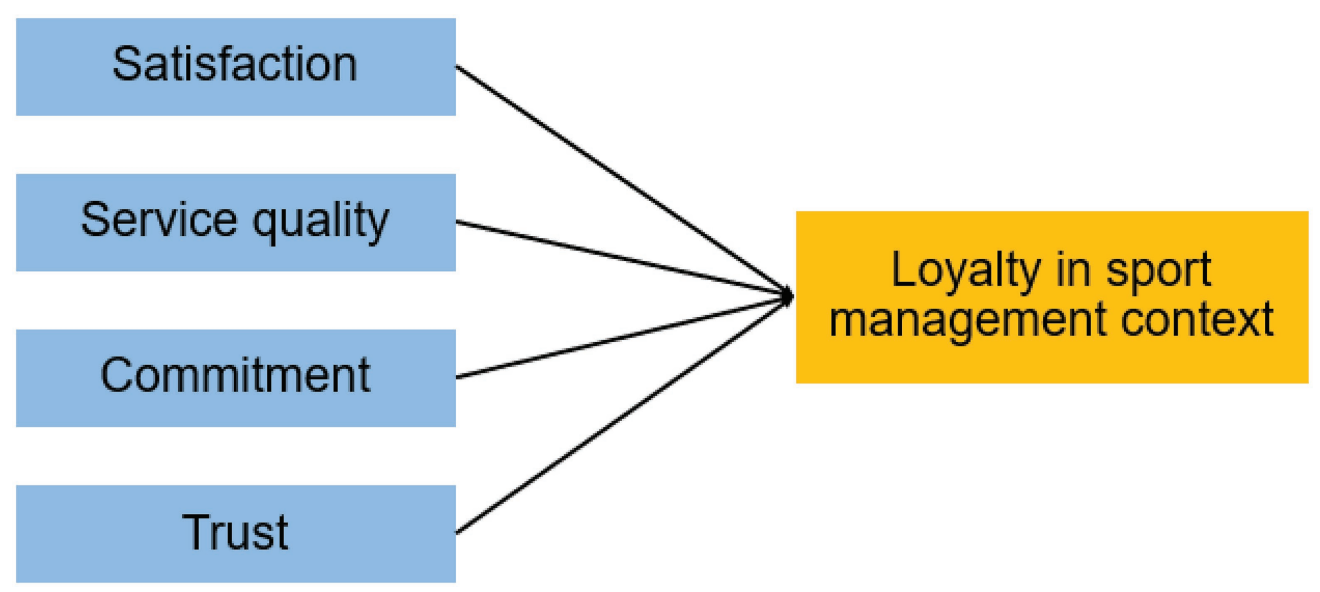

FIGURE 1 | Loyalty and its antecedents in a sport management context.

\section{Identification of studies via databases and registers}

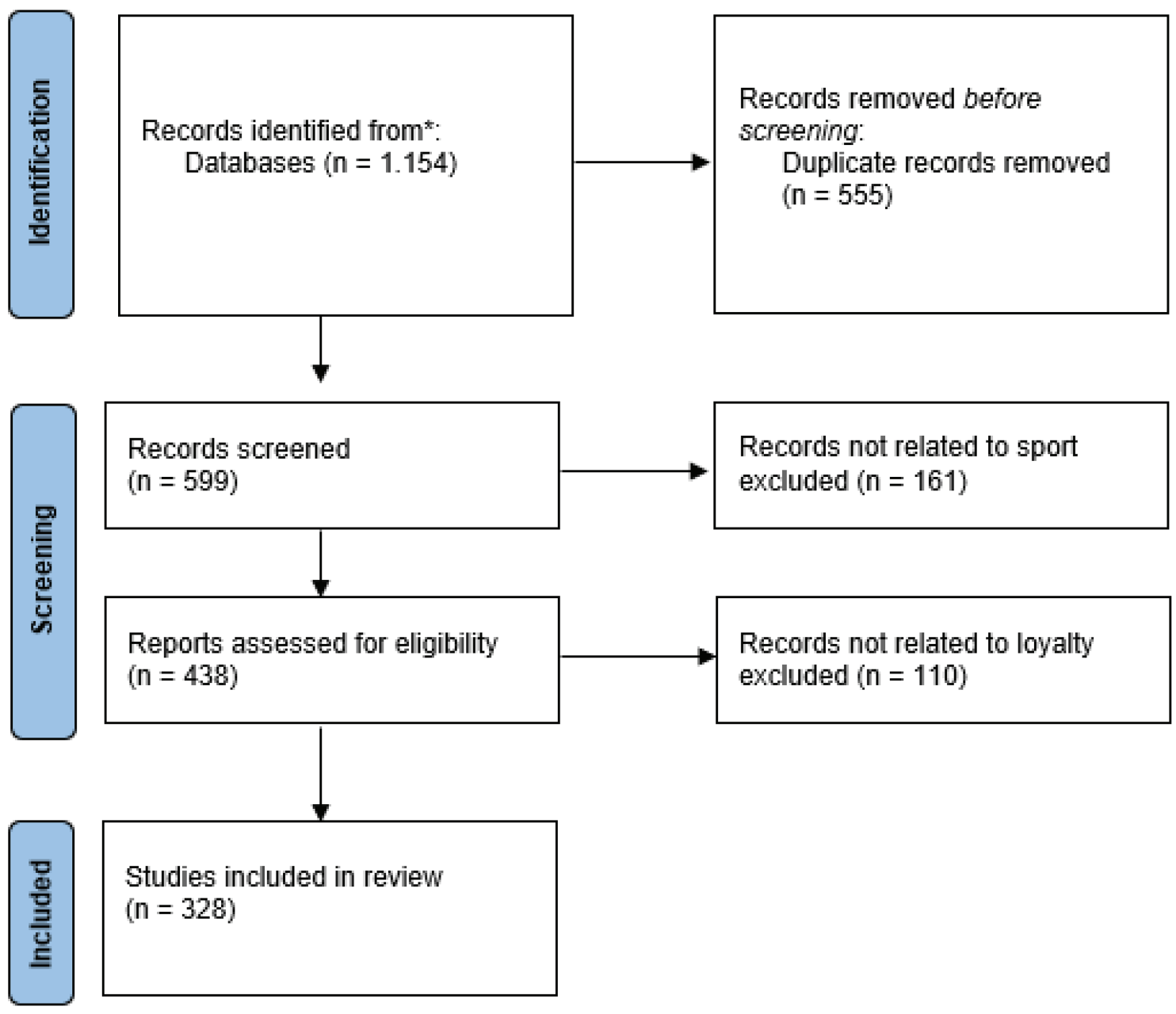

FIGURE 2 | PRISMA 2020 flow diagram for new systematic reviews. 
(Oliver, 1999; Chaudhuri and Holbrook, 2001; Rauyruen and Miller, 2007).

Another term that can be linked to loyalty is "resistance to change," since this concept appears in various definitions of loyalty (Oliver, 1999).

Resistance to change was a more common term in the literature than loyalty; however, in recent years loyalty has become much more popular, surpassing resistance to change.

Without any doubt, the term most used in theory is "behavior intentions," followed closely by "consumption behavior." Nevertheless, these two terms are much more general than loyalty and resistance to change, since they include loyalty and other variables such as word of mouth.

TABLE 6 | Number of papers and citations per author.

\begin{tabular}{lc}
\hline Author & Number of publications \\
\hline Funk, Daniel C. & 15 \\
Doyle, Jason & 10 \\
McDonald, Heath & 9 \\
Kunkel, Thilo & 9 \\
García-Fernández, Jerónimo & 8 \\
Author & Number of citations \\
Funk, Daniel C. & 473 \\
Yoshida, Masayuki & 274 \\
Heere, Bob & 259 \\
McDonald, Heath & 227 \\
Gordon, Brian & 205
\end{tabular}

(Boulding et al., 1993). In addition, most of the records obtained with the keyword "behavior intentions" and "consumption behavior" are duplicated in the other terms analyzed. Figure 4 presents all mentioned terms.

It is undoubtedly true that all types of sports organizations aspire to gain the loyalty of sports consumers. The literature includes various examples of the variables that explain this loyalty. The most common loyalty antecedents in the general literature are satisfaction, quality of service, commitment, and trust. The question is whether this also occurs in the literature on loyalty in sport.

TABLE 7 | Number of publications and citations per journal.

\begin{tabular}{lc} 
Journal & Number of publication \\
\hline Sport Management Review & 34 \\
Journal of Sport Management & 19 \\
International Journal of Sports & 10 \\
Marketing \& Sponsorship & 9 \\
European Sport Management Quarterly & \\
Sport Business and Management- An & 9 \\
International Journal & \\
Journal & Number of citations \\
Sport Management Review & 1,034 \\
Journal of Sport Management & 929 \\
Internet Research & 192 \\
Journal of Sustainable Tourism & 180 \\
Journal of Travel Research & 156
\end{tabular}

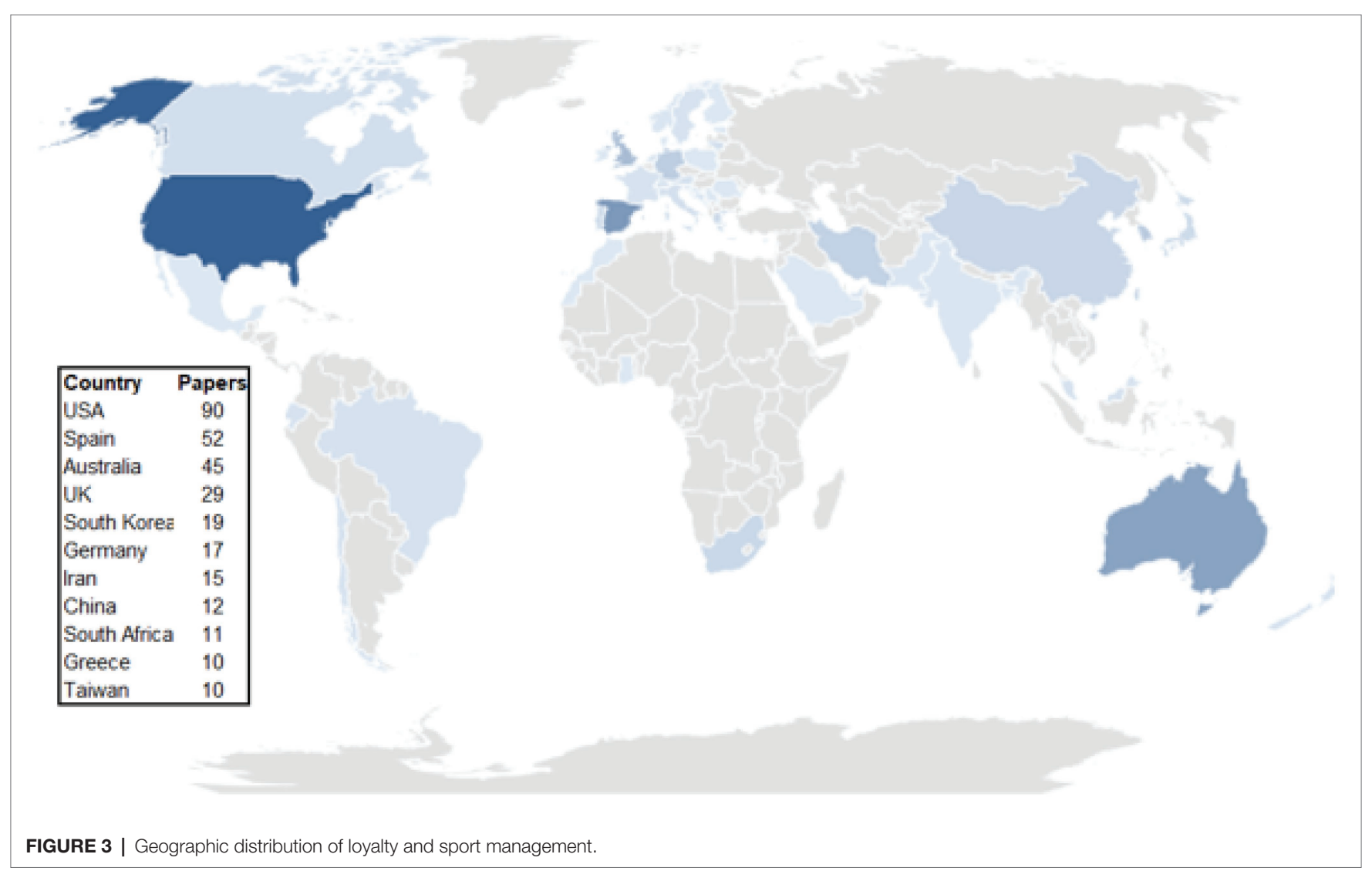




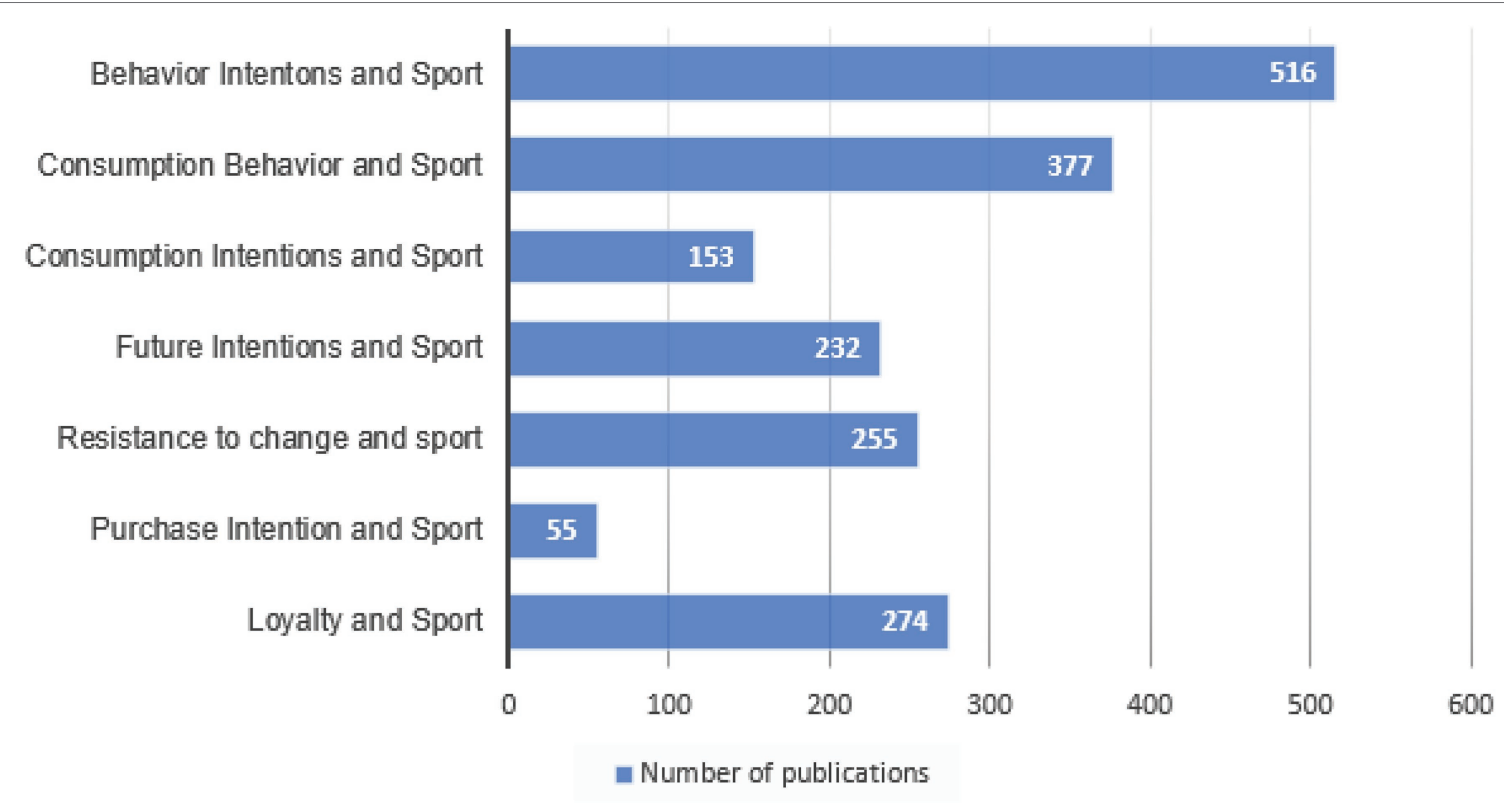

FIGURE 4 | Number of papers for loyalty in sport management and other terms related to loyalty.

Satisfaction is the variable most present in the literature on loyalty in the sports field. Another of the variables that has been most associated with loyalty is service quality. Figure $\mathbf{5}$ shows the percentage represented by each of the variables that explain loyalty in the articles studied.

Although the variables most found in the literature on loyalty in sport are satisfaction and service quality, the articles with the most citations do not study these variables, focusing instead on commitment and trust.

In total, there are 328 articles on loyalty in sport, of which five are those that study the four variables analyzed in this paper: satisfaction, service quality, commitment, and trust. Table 8 shows the five papers that includes all these variables.

\section{DISCUSSION AND CONCLUSION}

\section{Theorical and Managerial Discussions}

The loyalty variable has always been extensively researched in the field of literature of business field and more specifically in the sports field. Indeed, there is so much literature associated with loyalty in the field of sports management that it can be very difficult to navigate. The purpose of this paper, then, is to use a systematic review of more than 300 references to identify and classify the most relevant information on this topic and review the different factors and variables that define loyalty in sports management. Finally, it aims to check if these variables coincide with the most common variables in loyalty in general. This in turn requires an in-depth study of the variables that influence the loyalty.

Satisfaction is a crucial element of consumer loyalty; most studies that model loyalty include satisfaction as an explanatory variable, and, in practically, all cases they demonstrate its
TABLE 8 | Articles that include all analyzed variable.

\begin{tabular}{|c|c|c|}
\hline Title & References & Citations \\
\hline $\begin{array}{l}\text { Sustainable Management of Sports } \\
\text { Federations: The Indirect Effects of } \\
\text { Perceived Service on Member's Loyalty }\end{array}$ & $\begin{array}{l}\text { Cuesta-Valiño et al. } \\
\text { (2021c) }\end{array}$ & 0 \\
\hline $\begin{array}{l}\text { Built to last: relationship quality } \\
\text { management for season ticket holders }\end{array}$ & Lee et al. (2020) & 7 \\
\hline $\begin{array}{l}\text { Influence of Brand Image of a Sports } \\
\text { Event on the Recommendation of Its } \\
\text { Participants }\end{array}$ & $\begin{array}{l}\text { Martínez Cevallos } \\
\text { et al. (2020) }\end{array}$ & 2 \\
\hline $\begin{array}{l}\text { Perceived value, satisfaction and future } \\
\text { intentions in sport services Putting } \\
\text { congruence and brand trust in the } \\
\text { equation - linear models vs. QCA }\end{array}$ & Alguacil et al. (2019) & 2 \\
\hline $\begin{array}{l}\text { The Impact of Perceived Service Quality } \\
\text { on Customer Loyalty in Sports Clubs }\end{array}$ & Schijns et al. (2016) & 4 \\
\hline
\end{tabular}

positive influence (Dick and Basu, 1994; Oliver, 1999; Eriksson and Löfmarck Vaghult, 2000; Geyskens and Steenkamp, 2000; Rauyruen and Miller, 2007; Foroudi et al., 2016; Henseler et al., 2016; Cuesta-Valiño et al., 2019; Gutiérrez Rodríguez et al., 2020). Despite this, many authors consider that the relationship between satisfaction and loyalty is more complicated than it appears to be (Reichheld, 1993; Stauss and Neuhaus, 1997; Oliver, 1999; Bodet, 2012); satisfaction has a significant emotional component (Rauyruen and Miller, 2007) and this is influenced by the other variables (Parasuraman et al., 1988; Shane and Ulrich, 2004; Chiou and Drogue, 2006; Nemati et al., 2010; López-Sanz et al., 2021). In many cases, it acts as a mediating variable for other variables (Chiou and Drogue, 2006; Demirci and Kara, 2014; Abrudan et al., 2015; Foroudi et al., 2016; Kashif et al., 2016; Su et al., 2016), usually service quality. Service quality is clearly connected to satisfaction (Parasuraman 


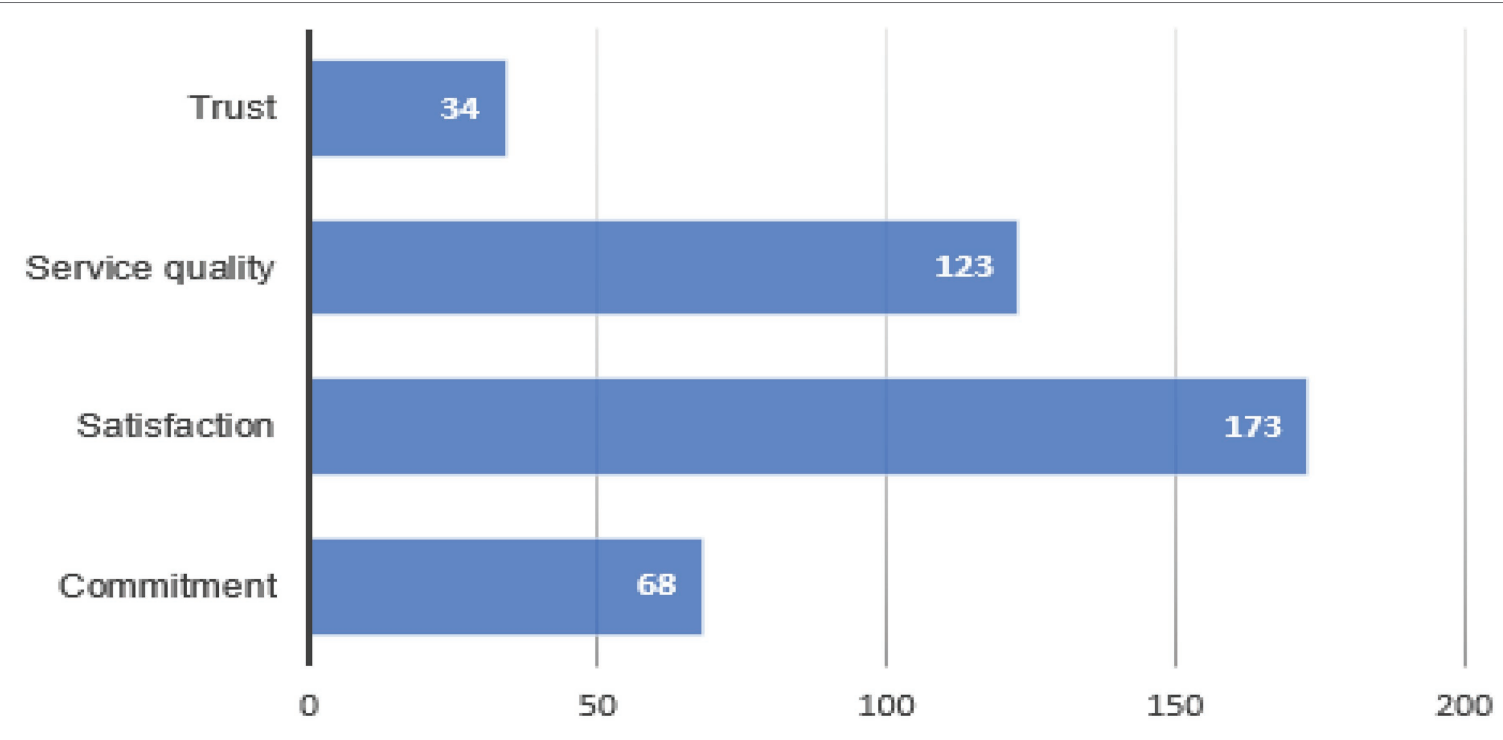

FIGURE 5 | Distribution of antecedents that explain loyalty over total publications.

et al., 1988; Pugh, 2001; Loranca-Valle et al., 2019) and both directly and indirectly to loyalty (Cronin and Taylor, 1992; Mandhachitara and Poolthong, 2011). These two variables are very present in the literature on sports management; in fact, taken together they explain loyalty in almost $75 \%$ of publications in this area. We find many examples of jobs both in the private sector (Bodet, 2012; Haro-González et al., 2018; CastilloRodríguez and Onetti-onetti, 2019) and in the public sector (García-Fernández et al., 2018; Cuesta-Valiño et al., 2021c).

The variables commitment and trust are much less present in the literature on loyalty in sports management than in other sectors such as the workplace. However, they cannot be ignored since articles that include these two variables in relation to loyalty have the best citation ratios: a very good indicator of the quality of these works. These two variables are definitely related to each other (Williamson, 1985; Gundlach et al., 1995; Garbarino and Johnson, 1999) and are also related to loyalty, especially in the case of non-profit organizations (Gruen et al., 2000; Galan-Ladero et al., 2013; Pressgrove and Mckeever, 2016; Barra et al., 2018) and those that are also sports-related (Ferrand et al., 2010; Kim et al., 2011). The two dimensions of both variables - cognitive and affective - are taken into account (Kumar et al., 1994; Johnson and Grayson, 2005; Rauyruen and Miller, 2007; Jones et al., 2010).

The country that produces the most publications on loyalty and sports management is the United States, which has 92 articles. This can logically be expected, since the United States is one of the countries that produces the most publications in general. In addition, many sports management magazines are from the United States, which favors the proliferation of works on these topics from that country.

It is curious that the second country with the most articles is Spain, since this country does not have the base and structure of resources that the United States has. This indicates the great interest in sport among Spanish researchers, as well as the specialization of the country's experts in these variables.

Daniel C. Funk could be considered as one of the greatest experts in sports management since he has published dozens of articles on this subject. According to the results of this study, he is also the author with the most published works on loyalty in the field of sport. Furthermore, he is the author with the most citations, which certifies the quality of his work. All the authors that appear in the list of results are major experts on the subject, since having more than seven publications on a specific topic is a sign of their knowledge on the subject. It is worth highlighting two authors: Heath McDonald, who appears in the top five for both number of publications and number of citations; and the Spaniard Jerónimo García-Fernández (eight articles), who appears in the top five for number of publications. He is likely to be one of the main reasons for Spain ranking second worldwide in number of publications.

Another conclusion derived from the results presented in this literature review is about the type of journals that publish on these topics. Unsurprisingly, focusing on specific sports management sources is the best option, since they are the ones that publish the most about loyalty in sport. However, other journals that may approach this topic and that may include call for papers on sports management should not be disregarded, even though sports management is not their main focus.

\section{Conclusion}

The subject selected for this systematic analysis of the literature has a wide variety of works. Sport generates great interest in society and therefore in the scientific community as well. This work attempts to order and classify the theory on loyalty and sports management and identify the main shortcomings of the scientific literature on this topic. 


\section{Limitations and Future Research}

The loyalty antecedents analyzed in this work have a strong presence in the theory; however, there are very few articles that present all the variables. From 328 articles found, only five consider satisfaction, service quality, commitment, and trust. Therefore, the approach of models that explain loyalty in the sports field offer an excellent starting point for continued research into this variable.

\section{DATA AVAILABILITY STATEMENT}

The raw data supporting the conclusions of this article will be made available by the authors, without undue reservation.

\section{REFERENCES}

Abrudan, I. N., Plăiaş, I., and Dabija, D. C. (2015). The relationship among image, satisfaction and loyalty - innovative factor of competitiveness for shopping Center. Amfiteatru Econ. 17, 536-552.

Alguacil, M., Núñez-Pomar, J., Pérez-Campos, C., and Prado-Gascó, V. (2019). Perceived value, satisfaction and future intentions in sport services: putting congruence and Brand Trust in the equation-linear models vs QCA. Acad. Rev. Latinoam. Adm. 32, 566-579. doi: 10.1108/ARLA-04-2019-0099

Anderson, E., Fornell, C., and Lehmann, D. (1994). Customer satisfaction, market share, and profitability: findings from Sweden. J. Mark. 58, 53-66. doi: $10.1177 / 002224299405800304$

Anderson, E., and Weitz, B. (1989). Determinants of continuity in conventional Industrial Channel dyads. Mark. Sci. 8, 310-323. doi: 10.1287/mksc.8.4.310

Andreassen, T. W. (2000). Antecedents to satisfaction with service recovery. Eur. J. Mark. 34, 156-175. doi: 10.1108/03090560010306269

Bansal, H. S., Irving, P. G., and Taylor, S. F. (2004). A three-component model of customer commitment to service providers. J. Acad. Mark. Sci. 32, 234-250. doi: $10.1177 / 0092070304263332$

Barra, C., Pressgrove, G., and Torres, E. (2018). Trust and commitment in the formation of donor loyalty. Serv. Ind. J. 38, 360-377. doi: 10.1080/02642069.2017. 1405937

Berry, L. (1995). Relationship Marketing of Services Growing Interest, emerging perspectives. J. Acad. Mark. Sci. 23, 236-245. doi: 10.1177/009207039502300402

Bodet, G. (2012). Loyalty in sport participation services: An examination of the mediating role of psychological commitment. J. Sport Manag. 26, 30-42. doi: 10.1123 /jsm.26.1.30

Boulding, W., Kalra, A., Staelin, R., and Zeithaml, V. A. (1993). A dynamic process model of service quality: From expectations to Behavioral intentions. J. Mark. Res. 30, 7-27. doi: 10.1177/002224379303000102

Butt, M. M., and de Run, E. C. (2010). Private healthcare quality: applying a SERVQUAL model. Int. J. Health Care Qual. Assur. 23, 658-673. doi: 10.1108/09526861011071580

Buttle, F. (1996). SERVQUAL: review, critique, research agenda. Eur. J. Mark. 30, 8-32. doi: 10.1108/03090569610105762

Castillo-Rodríguez, A., and Onetti-Onetti, W. (2019). Perceived quality in sports Centers in southern Spain: A case study. Sustainability 11, 3983-3991. doi: $10.3390 /$ su11143983

Chang, Y. H., and Yeh, C. H. (2002). A survey analysis of service quality for domestic airlines. Eur. J. Oper. Res. 139, 166-177. doi: 10.1016/S0377-2217(01)00148-5

Chaudhuri, A., and Holbrook, M. B. (2001). The chain of Effects from Brand Trust and brand affect to brand performance: The role of brand loyalty. J. Mark. 65, 81-93. doi: 10.1509/jmkg.65.2.81.18255

Chen, C. F., and Chen, F. S. (2010). Experience quality, perceived value, satisfaction and Behavioral intentions for heritage tourists. Tour. Manag. 31, 29-35. doi: 10.1016/j.tourman.2009.02.008

Chiou, J.-S., and Drogue, C. (2006). Service quality, trust, specific asset investment, and expertise: direct and indirect effects in a satisfaction-loyalty framework. J. Acad. Mark. Sci. 34, 613-627. doi: 10.1177/0092070306286934

\section{AUTHOR CONTRIBUTIONS}

All authors contributed to conception and design of the research, reviewed the theorical background, organized the database, performed the bibliometric analysis, wrote all the sections of the manuscript, contributed to manuscript revision, read, and approved the submitted version.

\section{ACKNOWLEDGMENTS}

The authors want to thank the collaboration of the Research Group of University of Alcalá: Consumer Behaviour, Organisational, and Market Analytics.

Cossío-Silva, F.-J., Revilla-Camacho, M.-A., Vega Vazquéz, M., and Palacios Florencio, B. (2016). Value co-creation and customer loyalty. J. Bus. Res. 69, 1621-1625. doi: 10.1016/j.jbusres.2015.10.028

Cronin, J. J. Jr., and Taylor, S. A. (1992). Measuring service quality: A Reexamination and extension. J. Mark. 56, 55-68. doi: 10.1177/ 002224299205600304

Cuesta-Valiño, P., Gutiérrez Rodríguez, P., and Núñez-Barriopedro, E. (2019). The impact of corporate social responsibility on customer loyalty in hypermarkets: A new socially responsible strategy. Corporate Soc. Res. Environ. 26, 761-769. doi: 10.1002/csr.1718

Cuesta-Valiño, P., Gutiérrez-Rodríguez, P., and Loranca-Valle, C. (2021c). Sustainable Management of Sports Federations: The indirect effects of perceived service on Member's loyalty. Sustainability 13:458. doi: 10.3390/ su13020458

Cuesta-Valiño, P., Gutiérrez-Rodríguez, P., and Núnez-Barriopedro, E. (2021a). The role of consumer happiness in brand loyalty: a model of the satisfaction and brand image in fashion. Corporate Govern. [Ahead of preprint]. doi: 10.1108/CG-03-2021-0099

Cuesta-Valiño, P., Loranca-Valle, C., and Núñez-Barriopedro, E. (2020). La Promoción del Deporte a través de la Felicidad del Deportista Federado en Kárate. ADResearch ESIC. 21, 48-69. doi: 10.7263/adresic-021-03

Cuesta-Valiño, P., Loranca-Valle, C., and Núñez-Barriopedro, E. (2021b). "Management of the Loyalty of the federated karate athlete and its correlation with happiness," in Happiness Management and Social Marketing: A Wave of Sustainability and Creativity. ed. R. Ravina Ripoll (Bern, Switzerland: Editorial Peter Lang), 39-53.

Demirci, F., and Kara, A. (2014). Supermarket self-checkout service quality, customer satisfaction, and loyalty: empirical evidence from an emerging market. J. Retail. Consum. Serv. 21, 118-129. doi: 10.1016/j.jretconser. 2013.07.002

Dick, A. S., and Basu, K. (1994). Customer loyalty: Toward an integrated conceptual framework. J. Acad. Mark. Sci. 22, 99-113. doi: 10.1177/ 0092070394222001

Dwyer, B., Greenhalgh, G. P., and LeCrom, C. W. (2015). Exploring fan behavior: developing a scale to measure sport EFANgelism. J. Sport Manag. 29, 642-656. doi: 10.1123/JSM.2014-0201

Dwyer, F. R., Schurr, P. H., and Oh, S. (1987). Developing buyer-seller relationships. J. Mark. 51, 11-27. doi: 10.1177/002224298705100202

Eriksson, K., and Löfmarck Vaghult, A. (2000). Customer retention, purchasing behavior and relationship substance in professional services. Ind. Mark. Manag. 29, 363-372. doi: 10.1016/j.ijinfomgt.2009.10.001

Farooq, M., Khalil, F., Tijjani, D., Younas, W., Sajjad, S., and Zreen, A. (2019). Service quality analysis of private universities libraries in Malaysia. Int $J$ Qual Res. 13, 269-284. doi: 10.24874/IJQR13.02-02

Ferrand, A., Robinson, L., and Valette-Florence, P. (2010). The intention-torepurchase paradox: A case of the health and fitness industry. J. Sport Manag. 24, 83-105. doi: 10.1123/jsm.24.1.83

Fornell, C. (1992). A National Customer Satisfaction Barometer the Swedish experience. J. Mark. 56, 6-21. doi: 10.1177/002224299205600103 
Foroudi, P., Zhongqi, J., Gupta, S., Melewar, T. C., and Mo, M. (2016). Influence of innovation capability and customer experience on reputation and loyalty. J. Bus. Res. 69, 4882-4889. doi: 10.1016/j.jbusres.2016.04.047

Galan-Ladero, M., Galera-Casquet, C., and Wymer, W. (2013). Attitudes towards cause-related marketing: determinants of satisfaction and loyalty. Int. Rev. Public Non Profit Mark. 10, 253-269. doi: 10.1007/s12208-013-0103-y

Garbarino, E., and Johnson, M. S. (1999). The different roles of satisfaction, trust, and commitment in customer relationships. J. Mark. 63, 70-87. doi: $10.1177 / 002224299906300205$

García-Fernández, J., Gálvez-Ruíz, P., Fernández-Gavira, J., Vélez-Colón, L., Pitts, B., and Bernal-García, A. (2018). The effects of service convenience and perceived quality on perceived value, satisfaction and loyalty in lowcost fitness Centers. Sport Manag. Rev. 21, 250-262. doi: 10.1016/j. smr.2017.07.003

Geyskens, I., and Steenkamp, J. B. E. (2000). Economic and social satisfaction: measurement and relevance to Marketing Channel relationships. J. Retail. 76, 11-32. doi: 10.1016/S0022-4359(99)00021-4

Geyskens, I., Steenkamp, J. E. M., Scheer, L. K., and Kumar, N. (1996). The effects of trust and interdependence on relationship commitment: A transAtlantic study. Int. J. Res. Mark. 13, 303-317. doi: 10.1016/S0167-8116 (96)00006-7

Gilbert, D., and Wong, R. K. (2003). Passenger expectations and airline services: A Hong Kong based study. Tour. Manag. 24, 519-532. doi: 10.1016/ S0261-5177(03)00002-5

Gruen, T. W., Summers, J. O., and Acito, F. (2000). Relationship marketing activities, commitment, and membership Behaviors in professional associations. J. Mark. 64, 34-49. doi: 10.1509/jmkg.64.3.34.18030

Gundlach, G. T., Achrol, R. S., and Mentzer, J. T. (1995). The structure of commitment in exchange. J. Mark. 59, 78-92. doi: 10.1177/002224299505900107

Gutiérrez Rodríguez, P., Ricardo Villarreal, R., Cuesta Valiño, P., and Blozis, S. (2020). A PLS-SEM approach to understanding E-SQ, E-satisfaction and E-loyalty for fashion E-retailers in Spain. J. Retail. Consumer Service. 57:102201. doi: 10.1016/j.jretconser.2020.102201

Gwinner, K. P., Dwayne, D. G., and Bitner, M. J. (1998). Relational benefits in services industries: The Customer's perspective. J. Acad. Mark. Sci. 26, 101-114. doi: 10.1177/0092070398262002

Haro-González, M., Pérez-Ordás, R., Grao-Cruces, A., Nuviala, R., and Nuviala, A. (2018). Female users of unisex fitness centres and of fitness centres exclusive for women: satisfaction. Int. J. Sports Mark. Spons. 19, 384-395. doi: 10.1108/ IJSMS-08-2016-0044

Hennig-Thurau, T., Gwinner, K. P., and Gremler, D. D. (2002). Understanding relationship marketing outcomes: An integration of relational benefits and relationship quality. J. Serv. Res. 4, 230-247. doi: 10.1177/1094670502004003006

Hennig-Thurau, T., Langer, M. F., and Hansen, U. (2001). Modeling and managing student loyalty: An approach based on the concept of relationship quality. J. Serv. Res. 3, 331-344. doi: 10.1177/109467050134006

Henseler, J., Hubona, G., and Ray, P. A. (2016). Using PLS path Modeling in new technology research: updated guidelines. Ind. Manag. Data Syst. 116, 2-20. doi: 10.1108/IMDS-09-2015-0382

Hult, G. T. M., Sharma, P. N., Morgeson, F. V. III, and Zhang, Y. (2019). Antecedents and consequences of customer satisfaction: do they differ across online and offline purchases? J. Retail. 95, 10-23. doi: 10.1016/j.jretai.2018.10.003

Hur, Y., Ko, Y. J., and Valacich, J. (2011). A structural model of the relationships Between sport website quality, E-satisfaction, and E-loyalty. J. Sport Manag. 25, 458-473. doi: 10.1123/jsm.25.5.458

Jacoby, J., and Kyner, D. B. (1973). Brand loyalty versus repeat purchase behavior. J. Mark. Res. 10, 1-9. doi: 10.1177/002224377301000101

Johnson, D., and Grayson, K. (2005). Cognitive and affective Trust in Service Relationships. J. Bus. Res. 58, 500-507. doi: 10.1016/S0148-2963(03)00140-1

Jones, T., Fox, G. L., Taylor, S. F., and Fabrigar, L. R. (2010). Service customer commitment and response. J. Serv. Mark. 24, 16-28. doi: 10.1108/ 08876041011017862

Józefowicz, B. (2013). “Trust in Creating pro-Developmental Positive Organisational Potential Outcomes," in Positive Management: Managing the Key Areas of Positive Organisational Potential for Company Success. ed. M. J. Stankiewicz (Toruń: Dom Organizatora TNOiK), 155-178.

Kashif, M., Rehman, M. A., and Pileliene, L. (2016). Customer perceived service quality and loyalty in Islamic banks A collectivist cultural perspective. TQM J. 28, 62-78. doi: 10.1108/TQM-01-2014-0006
Kim, Y. K., and Trail, G. (2011). A conceptual framework for understanding relationships Between sport consumers and sport organizations: A relationship quality approach. J. Sport Manag. 25, 57-70. doi: 10.1123/jsm.25.1.57

Kim, Y. K., Trail, G., and Ko, Y. J. (2011). The influence of relationship quality on sport consumption Behaviors: An empirical examination of the relationship quality framework. J. Sport Manag. 25, 576-592. doi: 10.1123/jsm.25.6.576

Kumar, N., Hibbard, J.D., and Stern, L.W. (1994). The Nature and Consequences of Marketing Channel Intermediary Commitment. Massachusetts: ReportMarketing Science Institute Cambridge.

Kunkel, T., Biscaia, R., and Arai, A.Agyemang (2019). The role of self-brand connection on the relationship between athlete brand image and fan outcomes. J. Sport Manag. 34, 201-216. doi: 10.1123/jsm.2019-0222

Kunkel, T., Funk, D., and Hill, B. (2013). Brand architecture, drivers of consumer involvement, and brand loyalty with professional sport leagues and teams. J. Sport Manag. 27, 177-192. doi: 10.1123/jsm.27.3.177

Lee, M. A., Kunkel, T., Funk, D. C., Karg, A., and McDonald, H. (2020). Built to last: relationship quality Management for Season Ticket Holders. Eur. Sport Manag. Q. 20, 364-384. doi: 10.1080/16184742.2019.1613438

Lee-Ross, D. (2008). An exploratory study of the contextual stability of SERVQUAL amongst three retail clusters in far North Queensland. J. Place Manag. Dev. 1, 46-61. doi: 10.1108/17538330810865336

Lewis, B. R., and Soureli, M. (2006). The antecedents of consumer loyalty in retail banking. J. Consum. Behav. 5, 15-31. doi: 10.1002/cb.46

López-Sanz, J. M., Penelas-Leguía, A., Gutiérrez-Rodríguez, P., and Cuesta-Valiño, P. (2021). Sustainable development and consumer behavior in rural tourismThe importance of image and loyalty for host communities. Sustainability 13:4763. doi: 10.3390/su13094763

Loranca-Valle, C., Cuesta-Valiño, P., and Núñez-Barriopedro, E. (2019). Gestión de calidad como estrategia clave de la felicidad en el deporte federado. Retos. Revista de Ciencias de la Administración y Economía 9, 203-218. doi: 10.17163/ret.n18.2019.02

Mahony, D. F., Madrigal, R., and Howard, D. A. (2000). Using the psychological commitment to team (PCT) scale to segment sport consumers based on loyalty. Sport Mark. Q. 9:15

Mandhachitara, R., and Poolthong, Y. (2011). A model of customer loyalty and corporate social responsibility. J. Serv. Mark. 25, 122-133. doi: $10.1108 / 08876041111119840$

Martínez Cevallos, D., Alguacil, M., and Calabuig Moreno, F. (2020). Influence of brand image of a sports event on the recommendation of its participants. Sustainability 12:5040. doi: 10.3390/su12125040

Maxham, J. G., and Netemeyer, R. G. (2002). A longitudinal study of complaining customers' evaluations of multiple service failures and recovery efforts. $J$. Mark. 66, 57-71. doi: 10.1509/jmkg.66.4.57.18512

Meesala, A., and Paul, J. (2018). Service quality, consumer satisfaction and loyalty in hospitals: thinking for the future. J. Retail. Consum. Serv. 40, 261-269. doi: 10.1016/j.jretconser.2016.10.011

Montero, A. A., and López-Sánchez, J. A. (2021). Intersection of data science and smart destinations: A systematic review. Front. Psychol. 12:712610. doi: 10.3389/fpsyg.2021.712610

Moorman, C., Deshpandé, R., and Zaltman, G. (1993). Factors affecting Trust in Market Research Relationships. J. Mark. 57, 81-101. doi: $10.1177 / 002224299305700106$

Morgan, R. M., and Hunt, S. D. (1994). The commitment-trust theory of relationship marketing. J. Mark. 58, 20-38. doi: 10.1177/002224299405800302

Mullin, B. J., Hardy, S., and Sutton, W. A. (2007). Marketing Deportivo. Barcelona: Paidotribo.

Nemati, A. R., Khan, K., and Iftikhar, M. (2010). Impact of innovation on customer satisfaction and brand loyalty, A study of Mobile phones users in Pakistan. Eur. J. Soc. Sci. 16, 299-306.

Núñez-Barriopedro, E., Cuesta-Valiño, P., Gutiérrez-Rodríguez, P., and Ravina-Ripoll, R. (2021). How does happiness influence the loyalty of karate athletes? A model of structural equations from the constructs: consumer satisfaction, engagement, and meaningful. Front. Psychol. 12:653034. doi: 10.3389/fpsyg.2021.653034

Oliver, R. L. (1980). A cognitive model of the antecedents and consequences of satisfaction decisions. J. Mark. 17, 460-469. doi: $10.1177 /$ 002224378001700405

Oliver, R. L. (1981). Measurement and evaluation of satisfaction processes in retailing settings. J. Retail. 57, 25-48. 
Oliver, R. L. (1999). Whence consumer loyalty. J. Mark. 63, 33-44. doi: 10.1177/00222429990634s105

Parasuraman, A., Zeithaml, V. A., and Berry, L. L. (1985). A conceptual model of service quality and its implications for future research. J. Mark. 49, 41-50. doi: 10.1177/002224298504900403

Parasuraman, A., Zeithaml, V. A., and Berry, L. L. (1988). Servqual: A multipleitem scale for measuring consumer Perc. J. Retail. 64, 12-28,

Pérez-Cabañero, C., Cervera-Taulet, A., and Schlesinger, W. (2017). Analysis of the impact of length of stay on the quality-of-service experience, satisfaction and loyalty. Int. Rev. Public Non Profit Mark 14, 253-268. doi: 10.1007/ s12208-016-0172-9

Pressgrove, G. N., and Mckeever, B. W. (2016). Nonprofit relationship management: extending the organization-public relationship to loyalty and Behaviors. J. Public Relat. Res. 28, 1-19. doi: 10.1080/1062726X.2016.1233106

Pugh, S. D. (2001). Service with a smile: emotional contagion in the service encounter. Acad. Manag. J. 44, 1018-1027. doi: 10.5465/3069445

Rather, R. A. (2018). Investigating the impact of customer brand identification on hospitality brand loyalty: A social identity perspective. J. Hosp. Mark. Manag. 27, 487-513. doi: 10.1080/19368623.2018.1404539

Rauyruen, P., and Miller, K. E. (2007). Relationship quality as a predictor of B2B customer loyalty. J. Bus. Res. 60, 21-31. doi: 10.1016/j.jbusres.2005.11.006

Reichheld, F. F. (1993). Loyalty-based management. Harv. Bus. Rev. 71, 64-73

Robledo, M. A. (2001). Measuring and managing service quality: integrating customer expectations. Manag. Serv. Qual. Int. J. 11, 22-31. doi: $10.1108 / 09604520110379472$

Ross, S., James, J., and Vargas, P. (2006). Development of a scale to measure team brand associations in professional sport. J. Sport Manag. 20, 260-279. doi: 10.1123 /jsm.20.2.260

Ruyter, K., Wetzels, M., and Bloemer, J. (1998). On the relationship between perceived service quality, service loyalty and switching costs. Int. J. Serv. Ind. Manag. 9, 436-453. doi: 10.1108/09564239810238848

Samen, A. A. A., Akroush, M. N., and Abu-Lail, B. N. (2013). Mobile SERVQUAL: A Comparativeanalysis of customers' and managers' perceptions. Int. J. Qual. Reliab. Manag. 30, 403-425. doi: 10.1108/02656711311308394

Sanz-Blas, S., Ruiz-Mafé, C., and Pérez, I. (2014). Key drivers of services website loyalty. Serv. Ind. J. 34, 37-41. doi: 10.1080/02642069.2014.871530

Schijns, J. M., Caniëls, M. C., and Le Conté, J. (2016). The impact of perceived service quality on customer loyalty in sports clubs. J. Sport Manag. Recreat. Tour. 24, 43-75.

Shane, S., and Ulrich, K. (2004). Technological innovation, product development, and entrepreneurship in management science. Manag. Sci. 50, 133-144. doi: $10.1287 / \mathrm{mnsc} .1040 .0204$

Sheth, J. N. (1996). "Relationship marketing: frameworks and concepts," in 1996 International Conference on Relationship Marketing: Development, Management and Governance of Relationships. March 29-31. Berlin, Germany.

Sirdeshmukh, D., Singh, J., and Sabol, B. (2002). Consumer trust, value, and loyalty. J. Mark. 66, 15-37. doi: 10.1509/jmkg.66.1.15.18449
Smith, A., and Stewart, B. (2013). "The special features of sport: A critical revisit," in Handbook of Research on Sport and Business (USA: Edward Elgar Publishing), 526-547.

Södergren, J. (2021). Brand authenticity: 25 years of research. Int. J. Consum. Stud. 45, 645-663. doi: 10.1111/ijcs.12651

Stauss, B., and Neuhaus, P. (1997). The qualitative satisfaction model. Int. J. Serv. Ind. Manag. 8, 236-249. doi: 10.1108/09564239710185424

Su, L., Swanson, S. R., and Chen, X. (2016). The effects of perceived service quality on repurchase intentions and subjective well-being of Chinese tourists: The mediating role of relationship quality. Tour. Manag. 52, 82-95. doi: 10.1016/j.tourman.2015.06.012

Szymanski, D. M., and Henard, D. H. (2001). Customer satisfaction: A metaanalysis of the empirical evidence. J. Acad. Mark. Sci. 29, 16-35. doi: 10.1177/0092070301291002

Trail, G. T., Anderson, D. F., and Fink, J. S. (2000). A theoretical model of sport spectator consumption behavior. Int. J. Sport Manag. 14, 154-178. doi: $10.1123 /$ jsm.14.2.154

Tsiotsou, R. H. (2013). Sport team loyalty: integrating relationship marketing and a hierarchy of effects. J. Serv. Mark. 27, 458-471. doi: 10.1108/ JSM-01-2012-0002

Wemmer, F., and Koenigstorfer, J. (2016). Open innovation in nonprofit sports clubs. Int. J. Volunt. Nonprofit Organ. 27, 1923-1949. doi: 10.1007/ s11266-015-9571-5

Williamson, O. E. (1985). The Economic Institutions of Capitalism. New York. Zablah, A., Carlson, B., Donavan, T., Maxham, J., and Brown, T. (2016). A cross-lagged test of the association Between customer satisfaction and employee job satisfaction in a relational context. J. Appl. Psychol. 101, 743-755. doi: 10.1037/apl0000079

Zeithaml, V. A. (1987). Defining and relating price, perceived quality, and perceived value. Cambridge, MA: Marketing Science Institute.

Conflict of Interest: The authors declare that the research was conducted in the absence of any commercial or financial relationships that could be construed as a potential conflict of interest.

Publisher's Note: All claims expressed in this article are solely those of the authors and do not necessarily represent those of their affiliated organizations, or those of the publisher, the editors and the reviewers. Any product that may be evaluated in this article, or claim that may be made by its manufacturer, is not guaranteed or endorsed by the publisher.

Copyright (C) 2021 Loranca-Valle, Cuesta-Valiño, Núnez-Barriopedro and GutiérrezRodríguez. This is an open-access article distributed under the terms of the Creative Commons Attribution License (CC BY). The use, distribution or reproduction in other forums is permitted, provided the original author(s) and the copyright owner(s) are credited and that the original publication in this journal is cited, in accordance with accepted academic practice. No use, distribution or reproduction is permitted which does not comply with these terms. 